\title{
Identification of testis 14-3-3 binding proteins by tandem affinity purification
}

\author{
Pawan Puri, ${ }^{1,+}$ Amparo Acker-Palmer, ${ }^{2}$ Ryan Stahler, ${ }^{1}$ Yijing Chen, ${ }^{1}$ Douglas Kline' and Srinivasan Vijayaraghavan ${ }^{1, *}$ \\ 'Department of Biological Sciences; Kent State University; Kent, $\mathrm{OH} ;{ }^{2} \mathrm{Cluster}$ of Excellence Macromolecular Complexes; Institute of Cell Biology and Neuroscience; Goethe \\ University; Frankfurt, Germany \\ ${ }^{+}$Current address: Department of Gynecology, Obstetrics and Reproductive Sciences; University of Pittsburgh School of Medicine; Magee-Women's Research Institute; \\ Pittsburgh, PA USA
}

Key words: 14-3-3, YWHA, protein phosphatase 1, spermatogenesis, tandem affinity purification

The 14-3-3 family of proteins interacts with various cellular phosphoproteins and regulates multiple cell signaling cascades. Identification of 14-3-3 interactors is important to define 14-3-3 functions in various biological pathways. The binding partners of protein 14-3-3 in testis are not known. The main goal of this study was to identify the 14-3-3 interactome in testis to determine the 14-3-3 regulated cellular processes in testis. We used transgenic mice expressing

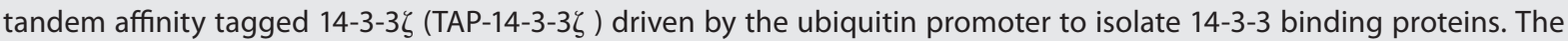
14-3-3 complexes in testis were isolated using a two-step tandem affinity purification (TAP) followed by identification with liquid chromatography/tandem mass spectrometry (LC-MS/MS). A total of 135 proteins were found to be associated with 14-3-3 in vivo in testis. Comparison of the testis 14-3-3 proteome with known 14-3-3 binding proteins showed that 71 of the proteins identified in this study are novel 14-3-3 interactors. Eight of these novel 14-3-3 interacting proteins are predominantly expressed in testis. The 14-3-3 interactors predominant in testis are: protein phosphatase1 $\gamma 2$ (PP1 $\gamma 2$ ), spermatogenesis associated 18 (SPATA18), phosphoglycerate kinase-2 (PGK2), testis specific gene A-2 (TSGA-2), dead box polypeptide 4 (DDX4), piwi homolog 1, protein kinase NYD-SP25 and EAN57. The fact that some of these proteins are indispensable for spermatogenesis suggests that their binding to 14-3-3 may be important for their function in germ cell division and maturation. These findings are discussed in context of the putative functions of 14-3-3 in spermatogenesis.

\section{Introduction}

The 14-3-3 proteins are a highly conserved family of acidic proteins expressed in a wide variety of cells and organisms ranging from yeast to plants and animals. The protein 14-3-3 was first identified as a protein activator of neuronal tyrosine hydroxylases. ${ }^{1}$ Seven mammalian isoforms of 14-3-3 are known: $\beta$, $\gamma, \varepsilon, \eta, \zeta, \theta, \sigma .^{2} 14-3-3$ interacts with the proteins containing phospho-serine and phospho-threonine residues within their RSXpSXP and RX(Y/F)XpSXP amino acid sequence motifs. ${ }^{3,4}$ Binding of 14-3-3 to its interacting proteins is usually phosphorylation dependent. ${ }^{5}$ The molecular and biochemical effects of 14-3-3 binding are diverse depending upon the nature of the interacting proteins and the pathways involved. 14-3-3 proteins have been shown to regulate the localization and phosphorylation status of proteins and modulate the activity of enzymes. ${ }^{6}$ 14-3-3 binds to over 300 proteins and regulates a wide variety of cellular pathways such as transcription, translation, splicing, protein trafficking and cell division. 14-3-3 mediated regulation of cell division is biochemically well defined. 14-3-3 is known to play a key regulatory role in both mitosis and meiosis.- ${ }^{7-9} 14-3-3$ prevents mitotic entry in Xenopus by binding to CDC25, a key cell cycle regulatory protein. ${ }^{9} 14-3-3$ acts as a negative factor in yeast meiosis by binding to phosphorylated Mei2p and inhibiting the meiosis inducing activity of Mei2p. ${ }^{8}$

Spermatogenesis is a complex process; in which sperm are produced by a series of mitotic divisions and a meiotic division followed by the post-meiotic maturation process called spermiogenesis. While it is known that 14-3-3 is expressed in testis however, the isoform specific expression of all seven 14-3-3 isoforms in various testicular cell types has not been well characterized..$^{10,11}$ The 14-3-3 isoforms, $\beta, \theta$ and $\varepsilon$ are expressed in rat testis and these three 14-3-3 isoforms are also reported to be expressed in Sertoli cells..$^{10-13}$ The 14-3-3 isoforms $\theta$ and $\varepsilon$ are expressed in testicular germ cells however the expression of 14-3-3 $\beta$ isoform is restricted to Sertoli cells and Leydig cells in rat testis. ${ }^{12,13}$ Functionally, $14-3-3 \theta$ is the most well-characterized isoform in testis. ${ }^{10,12,13}$ The 14-3-30 isoform expressed in testicular germ cells, forms a complex with Rap1/B-Raf in elongating spermatids. ${ }^{11}$ Recently, 14-3-30 isoform was also shown to regulate Sertoli-Sertoli cell adhesions in testis. ${ }^{13}$ The goal of this study was to isolate and identify 14-3-3 interacting proteins in testis to determine the cellular processes regulated by $14-3-3$ in testis. 14-3-3 interacting proteins in testis were identified by TAP. 
Transgenic mice expressing a TAP tag 14-3-3 protein under the ubiquitin promoter were used to isolate 14-3-3 binding proteins in testis. ${ }^{14}$ We identified a total of 135 14-3-3 interacting proteins, 8 of theses interactors are novel and expressed predominantly in testis.

\section{Results}

Expression and purification of TAP-14-3-3 from testis. To purify endogenous $14-3-3$ complexes in testis, transgenic mice expressing TAP 14-3-3 $\xi$, driven by the ubiquitin promoter were used (Fig. 1A). TAP tag is made up of a polypeptide segment containing a protein A moiety and calmodulin binding peptide (CBP) separated by a tobacco etch virus (TEV) cleavage site (Fig. 1B). Protein gel blot analysis of the wild type and transgenic mouse testis extracts with 14-3-3 antiserum revealed that the transgenic mice expressed the endogenous 14-3-3 (30 kDa) and the TAP tagged 14-3-3-fusion protein that migrated at $50 \mathrm{kDa}$ (Fig. 1C). To determine the testicular cell types in which TAP14-3-3 is expressed, we did immunohistochemistry analysis of wild type and transgenic mouse testis sections with purified rabbit IgG. The rabbit IgG specifically stained only the transgenic testis section because of its affinity for the protein A tag present in the TAP construct (Fig. 1D). Immuno-histochemistry analysis of the transgenic mouse testis-sections showed that the TAP-14$3-3 \zeta$, signal was present in cells within the seminiferous tubules as well as in the interstitial compartment of the testis (Fig. 1D).

TAP-14-3-3 $\zeta$ protein complexes in testis extracts were purified following the procedure outlined in Figure 2A. To determine whether the transgenically expressed TAP-14-3-3 $\zeta$ interacts with the endogenous 14-3-3 proteins, the products of each purification step were analyzed by immunoblotting with 14-3-3 antiserum. Protein gel blot analysis revealed that endogenous 14-3-3 iso-

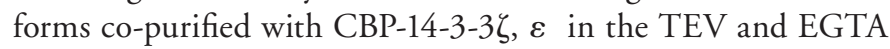
eluates (Fig. 2B). LC-MS/MS identified five different isoforms of 14-3-3, further confirming the ability of transgenically expressed TAP-14-3-3 $\zeta$, to properly fold and form homodimers and heterodimers with the endogenous 14-3-3 proteins. LC-MS/MS analysis also showed that the 14-3-3, isoform is acetylated at its $\mathrm{N}$-terminus (data not shown). In addition to 14-3-3 isoforms, a total of 130 proteins were identified by mass spectrometric analysis (Table 1). The 14-3-3 interacting proteins were grouped into categories based upon their previously defined biological functions. We also compared the 14-3-3 binding proteins identified in this study with other published $14-3-3$ proteomics studies. ${ }^{14-20}$ Of the 135 interacting proteins a total of 71 novel 14-3-3 binding proteins were identified. Eight of these novel 14-3-3 interacting proteins, predominantly expressed in testis are implicated in spermatogenesis. These are: spermatogenesis associated 18 (SPATA18), testis specific gene A2 (TSGA2), dead box polypeptide 4 (DdX4), Y-box-2, piwi homolog1, protein kinase NYD-25, spermatogenesis associated 20 and EAN57.

We have shown by GST-14-3-3 affinity chromatography that 14-3-3 interacts with PP1 $\gamma 2$ and PGK2 in bovine sperm in vitro, the enzymes essential for maintaining fertility. ${ }^{20-23}$ In this study LC-MS/MS analysis identified PGK2 as a 14-3-3 binding protein but surprisingly, we did not detect PP1 12 . To address this inconsistency, we performed TAP purification followed by protein gel blotting to determine whether 14-3-3 and PP1 $\gamma 2$ interact in vivo in the testis. Protein gel blot analysis of the EGTA eluate showed that PGK2 interacted with 14-3-3 in testis in vivo as expected (Fig. 3A). PP1 $\gamma 2$ was also detected in EGTA eluate by protein gel blotting thus defining $\mathrm{PP} 1 \gamma 2$ as a $14-3-3$ interacting protein in testis (Fig. 3B).

Mice lacking PP1 $\gamma$ are infertile and have hyper-phosphorylated PGK2 suggesting that PP1 $\gamma$ isoforms normally acts to maintain PGK2 in a dephosphorylated state. ${ }^{24}$ Because both PP1 22 and PGK2 bind with 14-3-3, the 14-3-3 protein may act as a scaffold to favor PP1 $\gamma 2$ and PGK2 interaction. 14-3-3 is known to act as a scaffold for signaling molecules in other cell types. $^{25}$ To determine whether 14-3-3, PP1 $\gamma 2$ and PGK-2 are present as a complex, we performed the first step of TAP purification (IgG purification) followed by PP1 $\gamma 2$ immunoprecipitation. First, the 14-3-3 complexes from the transgenic mice testes were captured on IgG beads and eluted by TEV cleavage. The TEV eluate containing the 14-3-3 complexes was subjected to PP1 $\gamma 2$ immunoprecipitation. Protein gel blot analysis of PP1 $\gamma 2$ immunoprecipitation eluate with 14-3-3 and PGK-2 antiserum showed that the endogenous 14-3-3, CBP-14-3-3 and PGK-2 co-precipitate with PP1 $\gamma 2$ (Fig. 3C). To further confirm this observation we used the first step of TAP purification (IgG purification step) coupled with microcystin affinity chromatography. Microcystin affinity chromatography has been previously used to isolate PP1 complexes. ${ }^{26}$ The TEV eluate containing 14-3-3 complexes was subjected to microcystin affinity chromatography to isolate PP1 and the associated proteins. Protein gel blot analysis of microcystin eluate confirmed that endogenous 14-3-3, CBP-14-3-3 and PGK-2 can be co-purified with PP1 (Fig. 3D-F).

Because proteins interacting with PP1 are known to regulate PP1 activity, it was of interest to determine whether PP1 12 bound to 14-3-3 was catalytically active. We found that PP1 complexed to 14-3-3 was catalytically active and could dephosphorylate its substrate, phosphorylase $a$, in an in vitro phosphatase assay (Fig. 4A). We tested whether the activity of PP1 22 bound to 14-3-3 can be inhibited by a phosphatase inhibitor, okadaic acid. Okadaic acid is a well-characterized inhibitor of phosphatases that inhibits PP2A at nanomolar concentrations and PP1 at micromolar concentrations. PP2A activity could be inhibited with $5 \mathrm{nM}$ okadaic acid. The activity of both PP2A and PP1 could be inhibited to basal levels with $1 \mu \mathrm{M}$ okadaic acid (Fig. 4A). These observations indicate that $56 \%$ of phosphatase activity is due to PP2A and $44 \%$ is due to PP1. Protein gel blot analysis of TEV eluate of TAP-14-3-3 probed with PP2A and PP1 $\gamma 2$ antibodies indeed confirmed the presence of PP2A and PP1 $\gamma 2$ (Fig. 4B). Thus both the serine/threonine phosphatases, PP1 $\gamma 2$ and PP $2 \mathrm{~A}$ bind to 14-3-3 in vivo.

A spermatogenesis-associated protein (SPATA18) identified in the LC-MS/MS has multiple 14-3-3 binding domains. To further confirm the interaction between 14-3-3 and SPATA18, HEK293 cells were co-transfected with His-SPATA18 and Myc14-3-3 plasmids. Immunoprecipitation of His-SPATA18 with a His-tag antibody co-precipitated myc-14-3-3 confirming the 

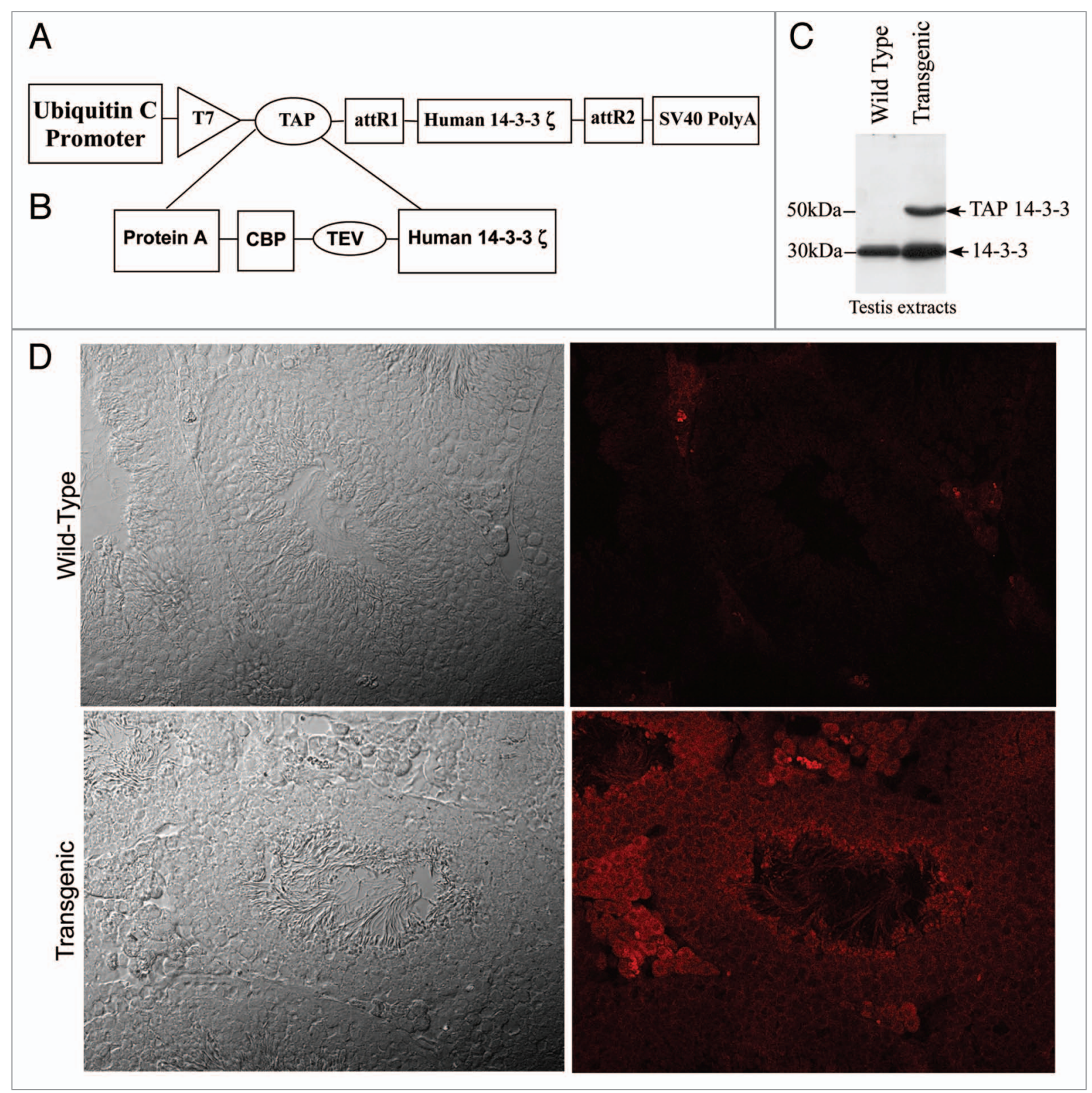

Figure 1. TAP 14-3-3 transgene construct plan and TAP 14-3-3 expression analysis in testis. (A) A Diagrammatic representation of the TAP 14-3-3 CDNA construct. (B) The TAP tag consisted of a protein A tag and a calmodulin binding peptide (CBP) separated by the TEV cleavage site sequence. The TAP

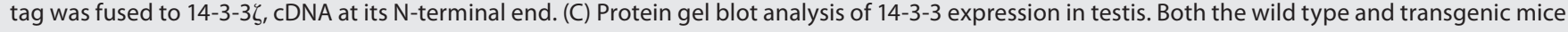
testes extracts showed endogenous 14-3-3 protein migrating at $30 \mathrm{kDa}$ whereas TAP 14-3-3 (50 kDa) could be detected only in the testis extracts of transgenic mice. (D) Immunohistochemical analysis of the TAP 14-3-3 transgenic mice testes showed that the TAP 14-3-3 is expressed in both the seminiferous tubules and the interstitial compartment of the testis. Testis sections from the wild type mice stained with rabbit lgG showed no fluorescence.

interaction between SPATA18 and 14-3-3 (Fig. 5A). Interestingly His-SPATA18 could also co-precipitate endogenous B-Raf kinase from HEK293 cells (Fig. 5B).

\section{Discussion}

In this study, we report the comprehensive 14-3-3 interactome of mouse testis. To isolate these testis 14-3-3 binding proteins we used transgenic mice expressing TAP-14-3-3 $\zeta$, driven by the ubiquitin promoter. ${ }^{14}$ TAP is a well-established method for isolation and identification of protein complexes in cells and tissues. ${ }^{27}$ The TAP is a sensitive and selective method that is particularly suited for isolating multimeric protein complexes in their native environment within cells. ${ }^{28}$ The two step procedure efficiently reduces the non-specific binding of background proteins.

The levels of transgenically expressed TAP-14-3-3 were found to be comparable to the levels of endogenous 14-3-3. Immunoblotting and LC-MS/MS analysis revealed that the transgenically expressed TAP-14-3-3 could form heterodimers with at least five endogenous 14-3-3 isoforms. This observation suggests 


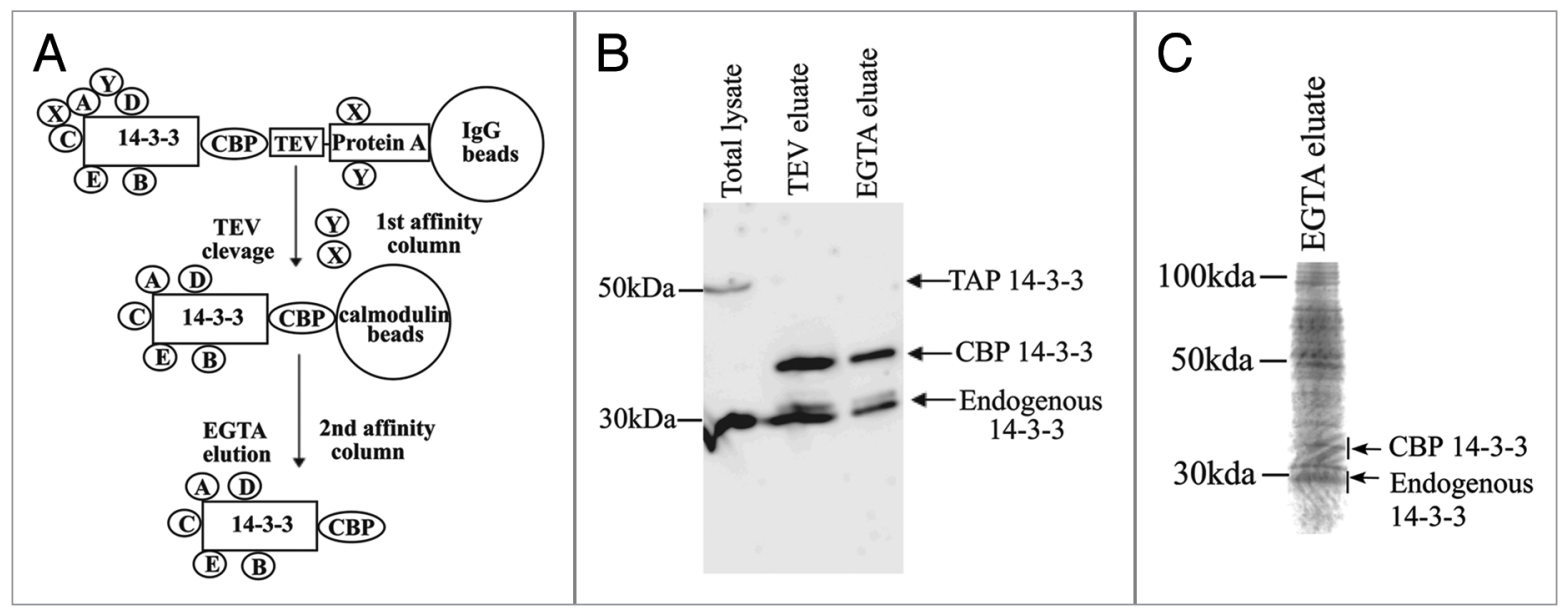

Figure 2. Tandem affinity purification. (A) A Schematic representation of the two steps of TAP-14-3-3 purification. The two-step procedure decreases the non-specific interactions. The purified proteins can be identified by protein gel blot analysis and/or mass spectrometry. (B) TAP-14-3-3 isolation was performed as described in the materials and methods. Detection of TAP-14-3-3 and endogenous 14-3-3 levels at each step of purification by protein gel blot analysis using an antibody against 14-3-3. (C) The EGTA eluate containing the 14-3-3 binding proteins was concentrated after TAP. The proteins were separated on a $12 \%$ SDS-PAGE stained with coomassie blue and the gel was used for the LC-MS/MS analysis.

that transgenic protein is properly folded and is able to form heterodimers with the endogenously expressed testis 14-3-3. The LC-MS/MS data showed that the 14-3-3 $\varepsilon$ isoform contained an acetylated $\mathrm{N}$-terminus. Acetylation of 14-3-3 isoforms has been reported to occur in Arabidopsis and mammals. ${ }^{29,30}$ It has been recently shown that 14-3-3 acetylation inhibits phosphorylation dependent interactions of $14-3-3 .{ }^{31}$ It is possible that $14-3-3 \varepsilon$ acetylation changes during various stages of spermatogenesis. Further studies are required to understand the dynamics and the physiological significance of acetylation specifically of the 14-3-3 $\varepsilon$ isoform in testis.

Comparison of the testis 14-3-3 interactome with the other 14-3-3 binding studies revealed that $53 \%$ of the proteins identified in the testis are novel whereas the remaining $47 \%$ have been previously identified 14-3-3 binding proteins. These earlier studies had used a variety of in vitro and in vivo approaches such as GST-14-3-3 affinity chromatography, 14-3-3 antibody affinity chromatography, quantitative immunoprecipitation combined with knockdown (QUICK), microarray analysis and TAP-14-3$3 . .^{14-19}$ Our study also identified five of the eight 14-3-3 interactions recently found to be highly conserved between Arabidopsis and Human 14-3-3 proteomes. ${ }^{32}$ These observations further establish the validity of the TAP-tag purification approach to isolate 14-3-3 binding proteins in testis. The proteins we have identified are likely to interact with 14-3-3 proteins in vivo, although it remains to be determined whether these proteins directly bind to $14-3-3$ or if their binding is part of a multimeric complexes.

Eight 14-3-3 interacting proteins are predominantly or exclusively expressed in testis (Table 1). Gene knockout studies have revealed that deletion of dead box polypeptide 4 (DDX4), TSGA-2 or Y box protein2 leads to infertility due to arrest of spermatogenesis. ${ }^{33-35}$ Dead box polypeptide isoforms have been identified as 14-3-3 binding proteins in other studies. ${ }^{15,16,36}$ DDX4 is the drosophila homolog of Vasa having DNA helicase activity. ${ }^{33,37}$ Protein kinase NYD-SP25, a member of tumor protein D52 family, is predominantly expressed in testis. ${ }^{38}$ Alternate splicing of tumor protein D52 isoform leads to generation of a 14-3-3 binding site. ${ }^{39} 14-3-3$ binding to DDX4 and protein kinase NYD-SP25 suggests a role of 14-3-3 in germ cell development. Further studies are required to determine how 14-3-3 binding regulates the function of these proteins in testis.

A substantial number of the proteins binding to 14-3-3 in testis are RNA binding proteins. These are; $\mathrm{KH}$ splicing regulatory protein, nucleolin, Piwi homolog 1, DDX4 and heteronuclear RNA binding proteins. Interaction of 14-3-3 to these RNA binding proteins have also been documented in other cells and tissues but the functional significance of these interactions is not clear. ${ }^{15-17}$ Some of these RNA binding proteins shuttle between the nucleus and the cytoplasm. ${ }^{40}$ It has been shown recently that 14-3-3 binding to the phosphorylated form of $\mathrm{KH}$ splicing regulatory protein sequesters the protein to the cytoplasm. ${ }^{41} \mathrm{It}$ is likely that 14-3-3 binding to these RNA binding proteins regulates their nuclear and cytoplasmic shuttling and localization.

Numerous studies have shown that the protein phosphatases

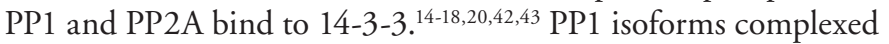
to $14-3-3$, dephosphorylate its binding partners and thereby regulate their interactions with 14-3-3. ${ }^{44}$ We recently showed that 14-3-3 interacts with PGK-2 and PP1 $\gamma 2$ in vitro and these three proteins might exist as a trimeric complex. ${ }^{20}$ In the present study we show that PP1 $\gamma 2$ and PGK-2 are present as a complex in testis in vivo. We also showed that PP1 12 bound to $14-3-3$ is catalytically active. Notably, a recent study has shown that PGK-2 is hyperphosphorylated in PP1 $\gamma$ knock out mouse testis extracts. ${ }^{24}$ Taken together, these observations suggest that PGK-2 is most likely a PP1 $\gamma 2$ substrate and 14-3-3 serves as a scaffolding protein. It would be interesting to determine how phoshorylation and/or 14-3-3 binding may regulate PGK-2 activity.

The testis specific protein, SPATA18 was identified as a 14-3-3 binding protein. SPATA18, a serine-arginine rich sperm protein 
Table 1. 14-3-3 binding proteins in testis identified by LC-MS/MS

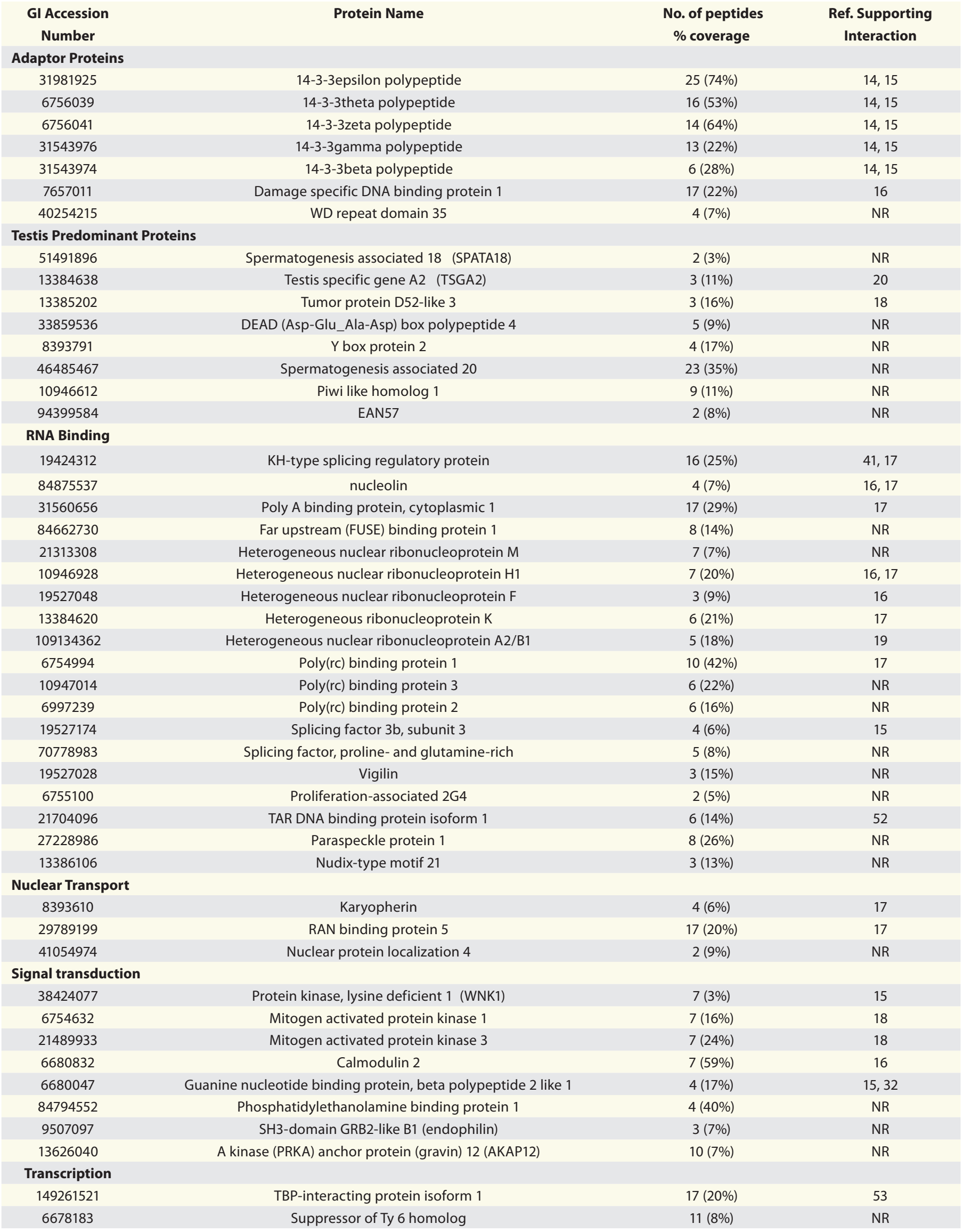


Table 1. 14-3-3 binding proteins in testis identified by LC-MS/MS (continued)

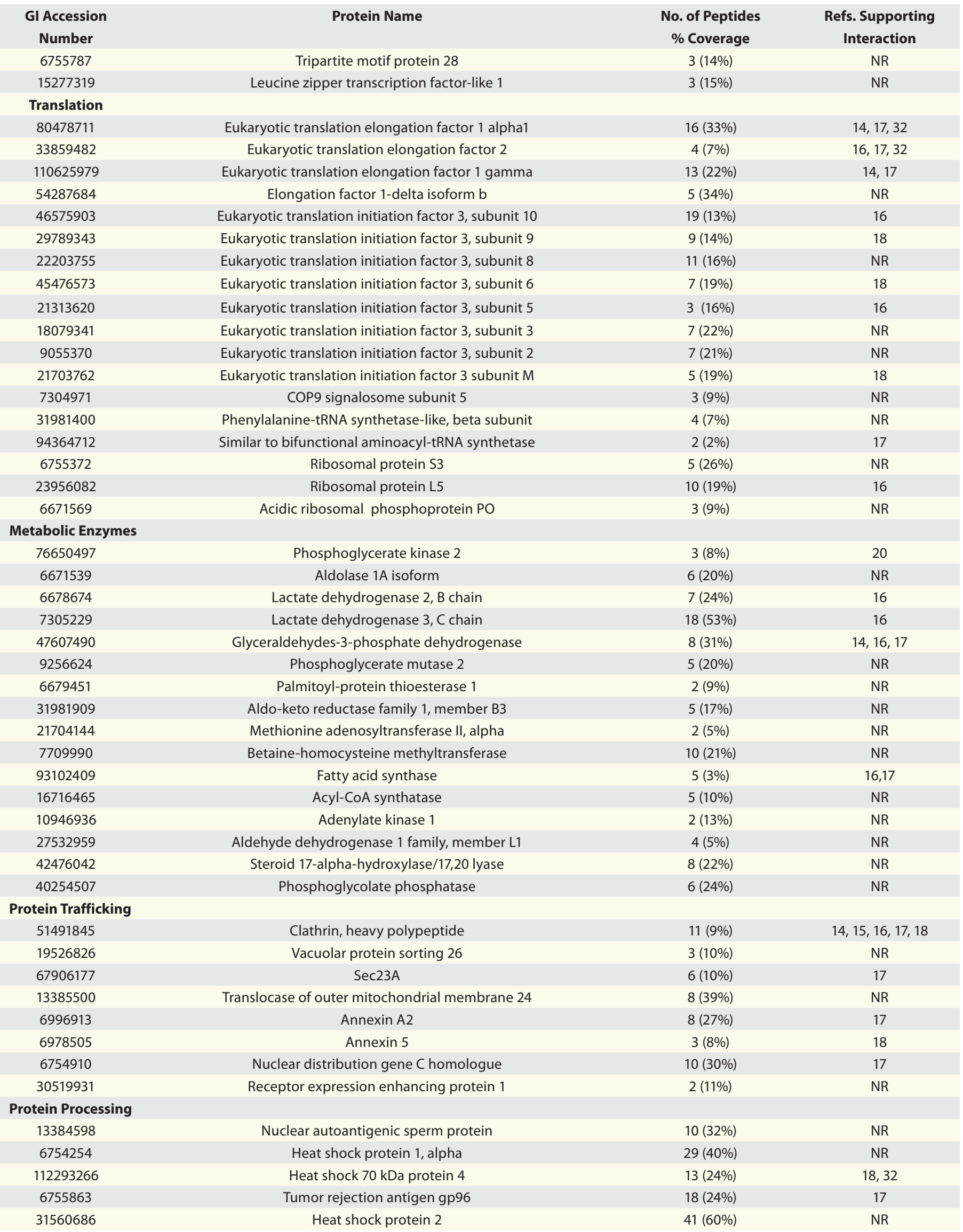


Table 1. 14-3-3 binding proteins in testis identified by LC-MS/MS (continued)

\begin{tabular}{|c|c|c|c|}
\hline $\begin{array}{l}\text { GI Accession } \\
\text { Number }\end{array}$ & Protein Name & $\begin{array}{l}\text { No. of Peptides } \\
\% \text { Coverage }\end{array}$ & $\begin{array}{l}\text { Refs. Supporting } \\
\text { Interaction }\end{array}$ \\
\hline 31981722 & Heat shock protein 5 & $21(33 \%)$ & 14 \\
\hline 31560613 & T-complex protein 1 subunit theta & $8(13) \%$ & NR \\
\hline 6753322 & T-complex protein 1 subunit delta & $9(14) \%$ & NR \\
\hline 6671700 & Chaperonin subunit 2 & $12(14 \%)$ & 15 \\
\hline 19526912 & Suppression of tumorigenicity 13 & $3(9 \%)$ & NR \\
\hline 110625998 & DnaJ homolog, subfamily B, member 11 & $6(19 \%)$ & NR \\
\hline 7305299 & Alpha-N-acetylglucosaminidase & $3(5 \%)$ & NR \\
\hline 13937367 & Phosducin like 2 & $3(16 \%)$ & 54 \\
\hline 112293264 & Protein disulphide isomerase associated 3 & $5(11 \%)$ & 17 \\
\hline 13507620 & Ankycorbin & $12(17 \%)$ & 17 \\
\hline 6755040 & Profilin 1 & $3(31 \%)$ & 16 \\
\hline 40254574 & Fatty acid-binding protein 9 & $3(38 \%)$ & NR \\
\hline \multicolumn{4}{|l|}{ Proteolysis } \\
\hline 30023842 & Valosin containing protein & $29(45 \%)$ & NR \\
\hline 31560449 & Aspartyl aminopeptidase & $8(14 \%)$ & 17 \\
\hline 9625047 & Ubiquitin-C terminal Hyrdolase 37 & $7(27 \%)$ & NR \\
\hline 58865870 & Ubiquitin carboxyl-terminal hydrolase L5 & $7(18 \%)$ & 18 \\
\hline 6755204 & proteasome subunit beta type- 5 & $4(27 \%)$ & 18 \\
\hline 33468885 & Calcyclin binding protein & $9(49 \%)$ & NR \\
\hline 6754084 & Glutathione $\mathrm{S}$ transferase, mu1 & $17(62 \%)$ & NR \\
\hline 6680121 & Glutathione $\mathrm{S}$ transferase, mu2 & $12(49 \%)$ & NR \\
\hline 6754086 & Glutathion S transferase, mu5 & $8(36 \%)$ & NR \\
\hline 6753762 & Epoxide hydrolase 1, microsomal & $6(12 \%)$ & NR \\
\hline 110735449 & Thioredoxin reductase 3 & $4(9 \%)$ & NR \\
\hline \multicolumn{4}{|c|}{ Unclassified/Hypothetical } \\
\hline 29244176 & Hypothetical protein LOC23967 & $5(12 \%)$ & NR \\
\hline 63485066 & Similar to translocated promoter region protein isoform 3 & $10(8) \%$ & NR \\
\hline 13386026 & Hypothetical protein LOC68045 & $3(26 \%)$ & NR \\
\hline 29244176 & Hypothetical protein $4732456 \mathrm{~N} 10$ & $5(12 \%)$ & NR \\
\hline
\end{tabular}

gets phosphorylated during epididymal sperm maturation. ${ }^{45}$ We also found that B-Raf interacts with SPATA18 in HEK293 cells. It may be possible that B-Raf is the kinase that phosphorylates SPATA18 in HEK293 cells and testis. SPATA18 is expressed in the cytoplasm of haploid spermatids in steps 7 to 18 and has been proposed to have a role in apoptosis. ${ }^{11,46} \mathrm{~B}$-Raf is known to bind to 14-3-3 in somatic cells and in differentiating haploid spermatids. ${ }^{11,47}$ SPATA18 binding to $14-3-3$ and B-raf suggests that SPATA18 may have a role in spermiogenesis. Proteins rich in serine-arginine repeats are known to bind to both 14-3-3 and PP1 and also contain both 14-3-3 and PP1 binding domains. ${ }^{48}$ The amino acid sequence of SPATA18 has multiple 14-3-3 binding domains and in addition also contains two RVXF motifs required for PP1 binding. However, we could not detect SPATA18 binding to PP1 $\gamma 2$ in the co-transfection experiments in HEK293 cells.

In this study, we show that tandem affinity purification in transgenic mice can be used to study the in vivo protein-protein 


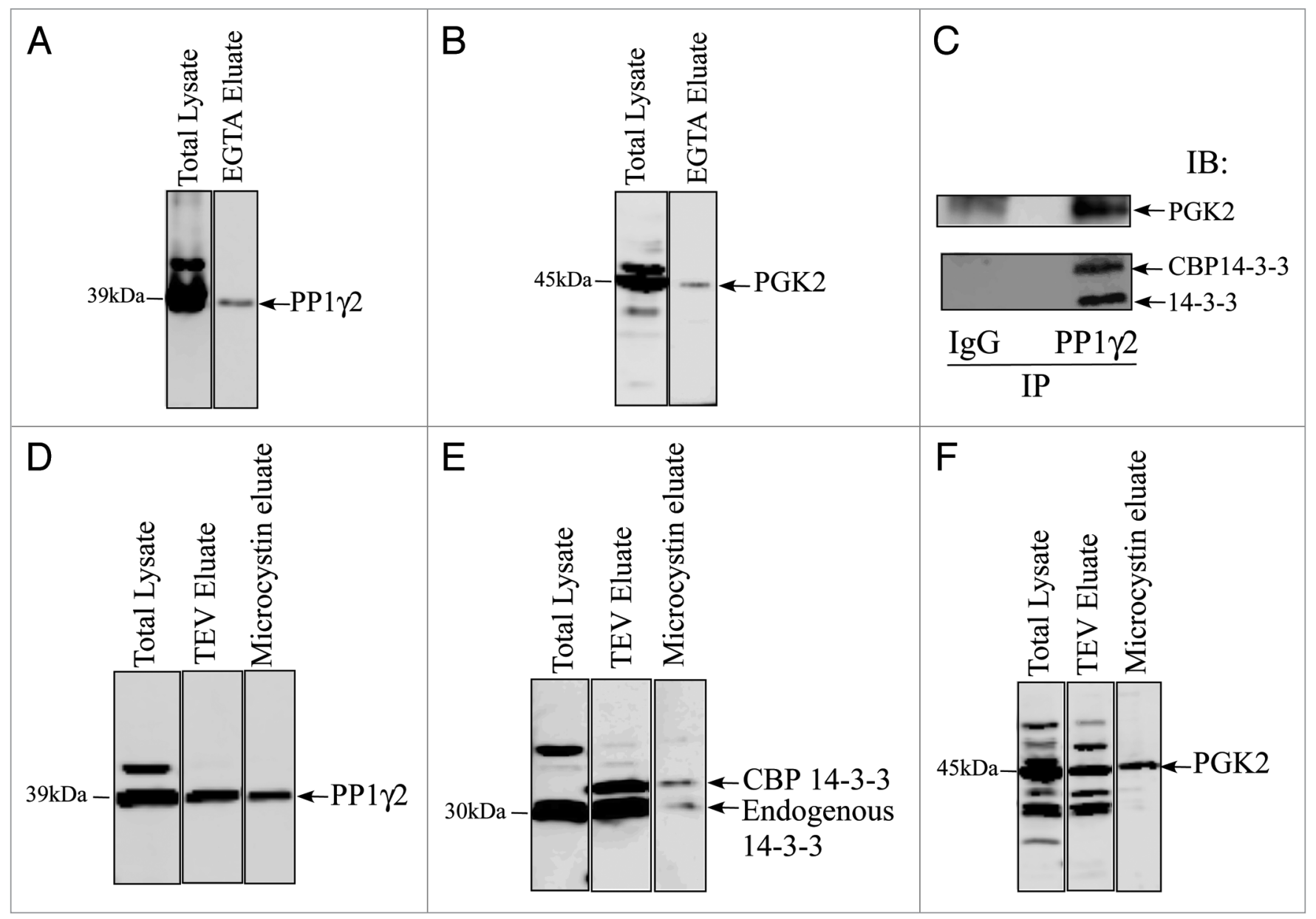

Figure 3. PP1 $\gamma 2$ and PGK2 are in an endogenous complex with 14-3-3. Total testis lysate and the EGTA eluate after TAP were resolved by SDS-PAGE and transferred on a PVDF membrane followed by immunoblot analysis with (A) PP1 $\gamma 2$ and (B) PGK2 antiserum. (C) The TAP-14-3-3 complexes were captured on IgG beads. The IgG beads were washed with wash buffer and 14-3-3 complexes were eluated after TEV clevage. The TEV eluate was incubated with purified IgG (as a control) or PP1 $\gamma 2$ antibody to immunoprecipitate PP1 $\gamma 2$. Immunoblotting analysis of the control and PP1 $\gamma 2$ immunoprecipation eluate showed that both 14-3-3 and PGK2 can be co-precipitated specifically with PP1 $\gamma 2$ from the TEV eluate. (D-F) 14-3-3 complexes from the TAP transgenic mice testis were purified by the first step of TAP purification on IgG beads. The 14-3-3 complexes were eluated by TEV cleavage. The TEV eluate was incubated with microcystin beads to isolate PP1 complexes. The microcystin eluate was analyzed by protein gel blotting with PP1 $\gamma 2,14-3-3$ and PGK2 antibodies.

interactions in testis. One major disadvantage of TAP technique is the relatively low yield of the TAP protein complexes. This is possibly due to interference by endogenous $\operatorname{IgG}$ in blood and by endogenous calmodulin in cells. However, this limitation of lower efficiency can be overcome by using a variety of newer versions of TAP tags, such as His, Flag and SBP tags that increase the yield of the purified complexes. ${ }^{49,50}$ The TAP technique can be further modified to identify stage and cell type specific protein interactomes by using well-characterized germ cell and testis somatic cell promoters to derive the bait protein expression to understand the molecular mechanisms involving 14-3-3 during spermatogenesis.

In summary, this is the first comprehensive analysis of testis specific 14-3-3 proteome in vivo. This inventory of 14-3-3 binding proteins we have identified would be valuable to direct future studies to determine function of 14-3-3 and its associated proteins in testis.

\section{Materials and Methods}

Transgenic mice expressing TAP-14-3-3. Transgenic mice (Mus musculus) and all other mice used in the experiments in this study were housed at Kent State University under an approved Institutional Animal Care and Use Committee protocol following the National Research Council's published Guide for the Care and Use of Laboratory Animals. Transgenic mice expressing TAP14-3-3 $\zeta$ driven by the ubiquitin promoter were generated as described..$^{14}$ The transgenic founders containing the TAP-14-3-3 $\zeta$ transgene were mated with out-bred CD1 mice to produce mice expressing TAP14-3-3 $\zeta$. Presence of the transgene was determined by polymerase-chain-reaction using primers complementary to the ubiquitin C promoter (5'-CAC CCG TTC TGT TGG CTT AT-3') and TAP cassette (5'-TGG CTG CTG AGA CGG CTA TGA-3') sequences. The PCR amplified an approximately $1 \mathrm{~kb}$ product corresponding to the transgene. 
Tissue extracts. Testes were collected from 3-6 mo old TAP 14-3-3 $\zeta$ transgene-positive mice. The tunica albuginea was removed and visible blood vessels were disrupted to remove blood in order to reduce potential contamination of the extracts with serum IgG, which is likely to interfere with the TAP tag isolation. Seminiferous tubules were washed with PBS followed by homogenization in the TAP purification buffer $50 \mathrm{mM}$ (TRIS-HCl, 150 $\mathrm{mM} \mathrm{NaCl}, 0.1 \% \mathrm{v} / \mathrm{v}$ NP- $40,1.5 \mathrm{mM} \mathrm{MgCl}, 5 \% \mathrm{v} / \mathrm{v}$ glycerol) containing phosphatase inhibitors $(5 \mathrm{mM}$ sodium pyrophosphate, $10 \mathrm{mM} \beta$-glycerophosphate, $50 \mathrm{mM}$ sodium fluoride) and protease inhibitors (complete protease inhibitor cocktail tablet, Roche Applied Sciences) pH 7.5 and centrifuged at 20,000x g for $30 \mathrm{~min}$. The supernatant was used for TAP. Phosphatase inhibitors were not included in testis extracts that were to be used for measuring the phosphatase activity.

Tandem affinity purification. IgG beads (IgG Sepharose G Fast Flow, GE Healthcare Life Sciences) were washed three times with the TAP purification buffer. The testis extracts $(10 \mathrm{ml})$ prepared from ten TAP-14-3-3 transgenic mice were incubated with $50 \mu \mathrm{lgG}$ beads for $4 \mathrm{~h}$ at $4^{\circ} \mathrm{C}$. IgG beads were washed three times with the Tobacco Etch Virus (TEV) cleavage buffer (50 $\mathrm{mM}$ TRIS-HCl, $0.5 \mathrm{mM}$ EDTA, $1 \mathrm{mM}$ dithiothreitol (DTT), $\mathrm{pH}$ 8.0). The TEV protease (50 U; Invitrogen) was added to 200 $\mu l$ of TEV cleavage buffer and the TAP14-3-3/IgG bead complex was incubated overnight at room temperature with rotation to cleave the complex at the TEV cleavage site, which would release the 14-3-3/CBP protein from the IgG beads. The eluate from the TEV cleavage step was diluted in 1:1 ratio in the calmodulin binding buffer (CBB) containing $50 \mathrm{mM}$ TRIS-HCl, 100 $\mathrm{mM} \mathrm{NaCl}, 10 \mathrm{mM}$ DTT, $2 \mathrm{mM} \mathrm{MgCl}$, 2 mM Imidazole, $0.1 \%$ NP-40, $10 \mathrm{mM} \beta$-mercaptoethanol, supplemented with $4 \mathrm{mM}$ $\mathrm{CaCl}_{2}$. Calmodulin beads $(50 \mu \mathrm{l}$ beads) (Calmodulin Affinity Resin, Stratagene) were washed with CBB. The 14-3-3/calmodulin binding protein complex was mixed by rotation with the calmodulin beads for $3 \mathrm{~h}$ at $4^{\circ} \mathrm{C}$. The beads were pelleted by centrifugation and washed twice with CBB. A $200 \mu \mathrm{l}$ aliquot of calmodulin elution buffer $(50 \mathrm{mM}$ TRIS-HCl, $20 \mathrm{mM}$ EGTA, $\mathrm{pH}$ 8.0) was added to release bound protein complexes ( $1 \mathrm{~h}$ with rotation at room temperature). The supernatant (final EGTA eluate) containing 14-3-3 (with CBP) and proteins bound to 14-3-3 was collected. For the large scale purification, a total of 60 mice were used and $-1,200 \mu \mathrm{l}$ final EGTA eluate was collected in six separate purifications from 10 mice each. The final EGTA eluate was concentrated to $-60 \mu \mathrm{l}$ by choloroform-methanol precipitation. The concentrated proteins were subjected to $12 \%$ SDS-PAGE, stained with colloidal Coomassie blue (Proteome Systems) and analyzed by protein gel blot and LC-MS/MA as described below.

LC-MS/MS analysis. For the protein digestion, the bands cut to minimize excess polyacrylamide, were divided into a number of smaller pieces, washed with water and dehydrated in acetonitrile. The bands were then alkylated with iodoacetamide prior to the in-gel digestion. All bands were digested in-gel using trypsin, by adding $5 \mu \mathrm{L} 20 \mathrm{ng} / \mu \mathrm{L}$ trypsin in $50 \mathrm{mM}$ ammonium bicarbonate and incubating overnight at room temperature to achieve complete digestion. The peptides that were formed were extracted from the

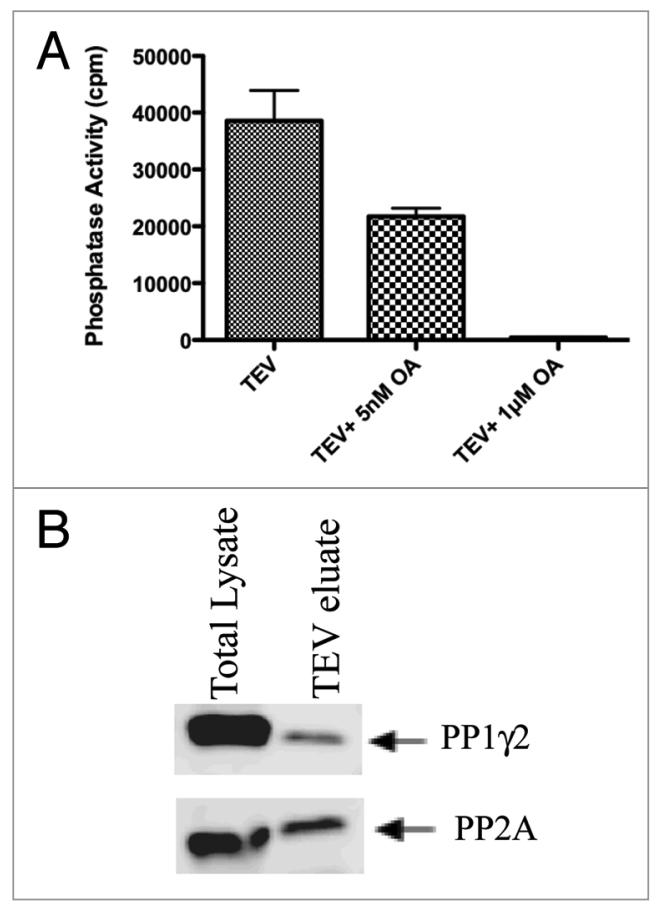

Figure 4. PP1 and PP2A bound to 14-3-3 are catalytically active. The TEV eluate isolated after first step of TAP purification was checked for the phosphatase activity of PP1 and PP2A as described in materials and methods. For protein phosphatase activity measurements, Phosphorylase $a$, a common substrate for both PP1 and PP2A was used. PP2A activity could be inhibited with $5 \mathrm{nM}$ okadaic acid. The activity of both PP2A and PP1 could be inhibited to basal levels with $1 \mu \mathrm{M}$ okadaic acid. (B) Protein gel blot analysis of the TEV eluate showed that both PP1 and PP2A interact with 14-3-3 in testis.

polyacrylamide in two aliquots of $30 \mu \mathrm{L} 50 \%$ acetonitrile with $5 \%$ formic acid. These extracts were combined and evaporated to $<10 \mu \mathrm{L}$ in Speedvac and then resuspended in $1 \%$ acetic acid to make up a final volume of $-30 \mu \mathrm{L}$ for LC-MS analysis.

The LC-MS system was a Finnigan LTQ linear ion trap mass spectrometer system. The HPLC column was a self-packed $9 \mathrm{~cm}$ x $75 \mu \mathrm{m}$ id Phenomenex Jupiter C18 reversed-phase capillary chromatography column. Two $\mu \mathrm{L}$ volumes of the extract were injected and the peptides eluted from the column by an acetonitrile $/ 0.05 \mathrm{M}$ acetic acid gradient at a flow rate of $0.3 \mu \mathrm{L} / \mathrm{min}$ were introduced into the source of the mass spectrometer online. The microelectrospray ion source is operated at $2.5 \mathrm{kV}$. The digest was analyzed using the data dependent multitask capability of the instrument acquiring full scan mass spectra to determine peptide molecular weights and product ion spectra to determine amino acid sequence in successive instrument scans. This mode of analysis produces approximately 2,500 collisionally induced dissociation (CID) spectra of ions ranging in abundance over several orders of magnitude. The data were analyzed by using all CID spectra collected in the experiment to search the NCBI non-redundant database with the search program Mascot using mammalian taxonomy filter. All matching spectra were verified by manual interpretation. The interpretation process was aided by additional searches using the programs Sequest and Blast as needed. 


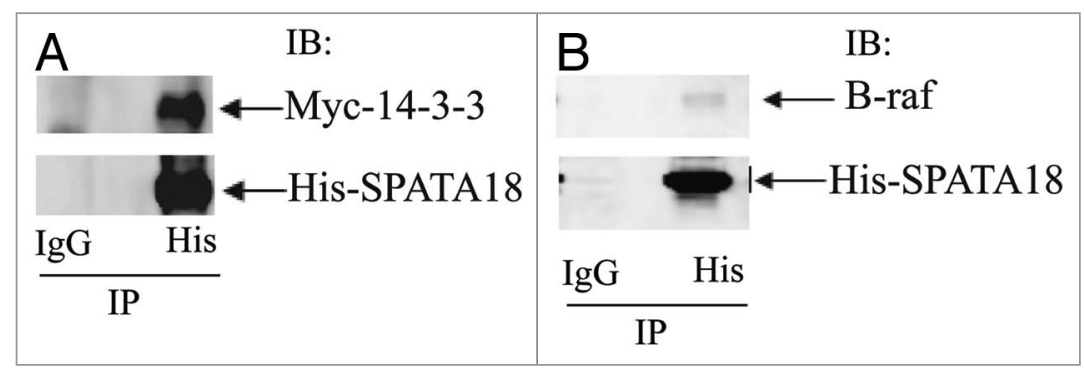

Figure 5. SPATA 18 interacts with 14-3-3 and B-raf. (A) HEK293 cells were transfected with pcDNA3.1 His-SPATA18 and pcDNA5.1 Myc-14-3-3 as described in materials and methods. The cell extracts were prepared $48 \mathrm{~h}$ after transfection and were subjected to Immunoprecipitation with the His-tag antibody and a control antibody. Immunoblotting of His-SPATA18 immuoprecipitates showed that Myc-14-3-3 (31 kDa) co-precipitate with His-SPATA18 ( 75 kDa). (B) HEK-293 cells were transfected with pcDNA3.1His-SPATA18 plasmid. The His-SPATA18 protein was immunoprecipitated with His-tag antibody and the immunoprecipation eluate was analyzed with anti-His and B-raf antibodies. B-raf $(\sim 85 \mathrm{kDa})$ co-precipitated with His-SPATA18.

Plasmid construction, cell culture and transfection. The SPATA18 cDNA, subcloned in pEXPRESS-I (Accession: NM_199374.2) was purchased from ATCC (American type culture collection). The SPATA cDNA was amplified by sense primer 5'-CTC GAA TTC ATG GCA GAG AAC TTG AAG AAG-3' and antisense primer 5'-CTC CTC GAG TTT AAT ACC TTG CGA ATG TAC ACC-3' and sub-cloned into pCDNA3.1 TOPO vector (Invitrogen). The SPATA18 TOPO plasmid and pCDNA 3.1HisC (Invitrogen) were restriction digested with EcoRI. The 14-3-3 cDNA was obtained from the pGEX-4T2 14-3-3 vector as previously described. ${ }^{20} \mathrm{~N}$-term myc tag pcDNA3.1 and pGEX-4T2 14-3-3 were digested with BamHI and EcoRI. The digested vector $(100 \mathrm{ng})$ was ligated overnight at $4^{\circ} \mathrm{C}$ with 30 ng of the insert. E. coli (Nova blue strain) was transformed with ligated product and bacterial colonies containing the SPATA18 and 14-3-3 cDNAs were identified by PCR. pCDNA3.1 HisC plasmid containing SPATA18 cDNA and N-term Myc-pcDNA containing 14-3-3 were amplified and purified by Qiagen midiprep kit. The subcloned products were sequenced to ensure that the plasmids contained the correct sequences. HEK293 cells were cultured in Dulbecco's modified eagle's medium (DMEM) (Invitrogen) containing 10\% fetal bovine serum (FBS). Cells were transfected with the pCDNA3.1HisC SPATA18 and Myc pcDNA 14-3-3 (for SPATA18 and 14-3-3 binding analysis) or pCDNA3.1HisC alone (for SPATA18 and B-raf interaction) using Lipofectamine 2000 (Invitrogen) as recommended by the manufacturer. The transfected HEK293 cells, after $48 \mathrm{~h}$ incubation, were washed twice with PBS and scraped in $1 \mathrm{ml}$ buffer $(50$ $\mathrm{mM}$ TRIS-HCl, $150 \mathrm{mM} \mathrm{NaCl}, 0.1 \% \mathrm{v} / \mathrm{v}$ NP-40) containing the phosphatase inhibitors $(5 \mathrm{mM}$ sodium pyrophosphate, 10 $\mathrm{mM} \beta$-glycerophosphate, $50 \mathrm{mM}$ sodium fluoride) and protease inhibitors (complete protease inhibitor cocktail tablet, Roche Applied Sciences), pH 7.5. Cells were disrupted by sonication $(3 \mathrm{x}$ for $3 \mathrm{sec}$ ) and centrifuged at 20,000x g for $30 \mathrm{~min}$. The supernatant was used for protein gel blot and immunoprecipitation analysis.
Protein phosphatase activity assay. Catalytic activity of PP1 and PP2A bound to TAP-14-3-3 was measured using Phosphorylase $a$ as a substrate. The Preparation of ${ }^{32} \mathrm{P}$ labeled phosphorylase $a$ for the measurement of phosphatase activity has been previously described..$^{51}$ Briefly, the substrate and the TAP-14-3-3/PP1 complex was incubated (in a total volume of $40 \mu \mathrm{l}$ ) at $30^{\circ} \mathrm{C}$ with $1 \mathrm{mM} \mathrm{Mn}^{2+}$ in the presence or absence of the protein phosphatase inhibitor okadaic acid (Calbiochem) $\left(\mathrm{IC}_{50} 5\right.$ $\mathrm{nM}$ for PP2A and $\mathrm{IC}_{50} 1 \mu \mathrm{M}$ for PP1) for $10 \mathrm{~min}$. At the end of this incubation, the reaction was terminated with $180 \mu \mathrm{l} 20 \%$ trichloro acetic acid (TCA) after which the tubes were centrifuged for $5 \mathrm{~min}$ at $16,000 \mathrm{xg}$ at $4^{\circ} \mathrm{C}$. The supernatants were analyzed for ${ }^{32} \mathrm{PO}_{4}$ released by the activity of the phosphatase.

Immunoprecipitation and microcystin affinity chromatography. Purified IgG as control (Jackson Immunoresearch) or anti-PP1 12 or anti-His (Invitrogen) antibodies were used at a final concentration of $2.5-4 \mu \mathrm{g}$ for immunoprecipiation. The HEK293 cell extracts $(400-500 \mu \mathrm{g})$ were incubated with control and anti-His antibody for $2 \mathrm{~h}$ at $4^{\circ} \mathrm{C}$. Protein A sepharose (Invitrogen) $35 \mu \mathrm{l}$ (50\% slurry) was washed three times with TTBS buffer and incubated with antibodysperm extract mixture at $4^{\circ} \mathrm{C}$ for $1 \mathrm{~h}$. The mixture was spun down at 900x g and beads were washed five times with buffer containing $50 \mathrm{mM}$ TRIS-HCl, $150 \mathrm{mM} \mathrm{NaCl}$ and $0.1 \% \mathrm{NP}-40$. The beads were boiled in $2 \mathrm{x}$ sample buffer for $5 \mathrm{~min}$ and the proteins were analyzed by protein gel blot analysis. To immunoprecipitate PP1 $\gamma 2$, the TEV eluate $(1 \mu \mathrm{g})$ was incubated with control IgG or PP1 $\gamma 2$ antibody $(1 \mathrm{mg})$. To purify the protein phosphatase complexes the TEV eluate was incubated with 20 $\mu \mathrm{l}$ of microcystin beads for $1 \mathrm{~h}$ at $4^{\circ} \mathrm{C}$ (Millipore.). The microcystin beads were washed five times with buffer containing 50 $\mathrm{mM}$ TRIS-HCl, $150 \mathrm{mM} \mathrm{NaCl}$ and $0.1 \% \mathrm{NP}-40$ and the PP1 complexes were eluated by boiling the beads in 2x sample buffer.

Protein gel blot analysis. Extracts boiled in Laemmli sample buffer were separated by $12 \%$ SDS-PAGE and electrophoretically transferred to Immobilon-P, PVDF membranes 90 (Millipore Corp., Bedford, MA). Nonspecific binding sites were blocked with $5 \%$ non fat dry milk in Tris-buffered saline (TBS; 25 $\mathrm{mM}$ TRIS-HCl, $\mathrm{pH} 7.4,0.15 \mathrm{M} \mathrm{NaCl}$, containing $0.1 \%$ Tween 20), blots were incubated overnight at $4^{\circ} \mathrm{C}$ with the appropriate primary antibody: anti-PP2A $(1: 1,000)$ (Upstate), anti-His$\operatorname{tag}(1: 5,000)$ (Invitrogen), anti B-Raf $(1: 1,000)$ (Cell Signaling Technology), anti-PP1 $\gamma 2(1: 2,000)$ (Zymed Laboratories) and anti-14-3-3 rabbit polyclonal (1:2,000) (Zymed Laboratories). Following this, the blots were washed and incubated for $1 \mathrm{~h}$ at room temperature with anti-mouse raised in donkey $(1: 10,000)$ (Genscript) for primary antibodies against PP2A, His tag and Actin or anti-rabbit antibodies raised in donkey $(1: 10,000)$ (Genscript) for B-Raf, PP1 $\gamma 2$ and 14-3-3 antibodies. Blots were washed and developed by homemade ECL.

Immunohistochemistry of mouse testis. Testes of both wild-type and TAP 14-3-3 transgenic mice were fixed in $4 \%$ 
paraformaldehyde in PBS for $40 \mathrm{~h}$. The testes then were transferred to $75 \%$ ethanol and dehydrated, permeabilized and embedded in paraffin using a Shandon Tissue Processor (Thermo Electron Corp., Waltham, MA). Multiple 8- $\mu \mathrm{m}$ thick sections of the whole testis were attached to poly-L-lysine-coated slides, deparaffinized and rehydrated using a standard procedure. Antigen retrieval was performed using 13 Antigen Retrieval Citra Solution (BioGenex, San Ramon, CA). Sections immersed in Citra solution were microwaved for three separate 3 min periods on high setting, with a cooling period of $1 \mathrm{~min}$ between each heating cycle. Sections were washed briefly in distilled water and then washed three times for 10 min with PBS. Sections were incubated for 1 $\mathrm{h}$ at room temperature in a blocking solution containing $10 \%$ normal goat serum in PBS. The slides then were incubated with purified rabbit $\operatorname{IgG}$ for overnight at $4^{\circ} \mathrm{C}$, washed three times with PBS and incubated with anti-rabbit secondary antibody $(1: 250)$ conjugated to indocarbocya-nine (Cy3; Jackson Laboratories, West Grove, PA) for $1 \mathrm{~h}$ at room temperature. The slides were washed five times with PBS, mounted with Vectashield (Vector Laboratories, Burlingame, CA) mounting media and examined using a FluoView 500 Confocal Fluorescence Microscope
(Olympus, Melville, NY). Control slides were processed in the same manner.

Statistical analysis. The data are represented as mean \pm standard error of mean (SEM). The data was analyzed by one way ANOVA.

\section{Disclosure of Potential Conflicts of Interest}

The authors declare that there is no conflict of interest that would prejudice the impartiality of this scientific work.

\section{Acknowledgements}

This research was Supported by National Institute of Health grant HD38520 to S.V and a Kent State University Graduate Student Senate grant to P.P. We thank Dr. Mike Kinter for doing LC-MS in Lerner Research Institute Proteomics laboratory, Cleveland. We also thank Dr. Deborah A. O’Brien (Department of Cell and Developmental Biology, University of North Carolina School of Medicine, Chapel Hill, NC for her generous gifts of PGK2 antibody. We also thank Dr. William H. Walker, Dr. Natalia Kostereva and Tejasvi Dudiki for their help in results and discussion.

\section{References}

1. Ichimura T, Isobe T, Okuyama T, Yamauchi T, Fujisawa $\mathrm{H}$. Brain $14-3-3$ protein is an activator protein that activates tryptophan 5-monooxygenase and tyrosine 3-monooxygenase in the presence of $\mathrm{Ca}^{2+}$, calmodulindependent protein kinase II. FEBS Lett 1987; 219:79 82; PMID:2885229; http://dx.doi.org/10.1016/00145793(87)81194-8

2. Ichimura T, Isobe T, Okuyama T, Takahashi N, Araki $\mathrm{K}$, Kuwano R, et al. Molecular cloning of cDNA coding for brain-specific 14-3-3 protein, a protein kinase-dependent activator of tyrosine and tryptophan hydroxylases. Proc Natl Acad Sci USA 1988; 85:70848; PMID:2902623; http://dx.doi.org/10.1073/ pnas.85.19.7084.

3. Muslin AJ, Tanner JW, Allen PM, Shaw AS. Interaction of 14-3-3 with signaling proteins is mediated by the recognition of phosphoserine. Cell 1996; 84:889-97; PMID:8601312; http://dx.doi.org/10.1016/S00928674(00)81067-3.

4. Yaffe MB, Rittinger K, Volinia S, Caron PR, Aitken A, Leffers $\mathrm{H}$, et al. The structural basis for 14-3-3: phosphopeptide binding specificity. Cell 1997; 91:961-71; PMID:9428519; http://dx.doi.org/10.1016/S00928674(00)80487-0.

5. Morrison DK. The 14-3-3 proteins: integrators of diverse signaling cues that impact cell fate and cancer development. Trends Cell Biol 2009; 19:16-23; PMID:19027299; http://dx.doi.org/10.1016/j. tcb.2008.10.003.

6. Bridges D, Moorhead GB. 14-3-3 proteins: a number of functions for a numbered protein. Sci STKE 2005; 2005:10.

7. Ozoe F, Kurokawa R, Kobayashi Y, Jeong HT, Tanaka $\mathrm{K}$, Sen $\mathrm{K}$, et al. The 14-3-3 proteins $\operatorname{Rad} 24$ and Rad25 negatively regulate Byr2 by affecting its localization in Schizosaccharomyces pombe. Mol Cell Biol 2002; 22:7105-19; PMID:12242289; http://dx.doi org/10.1128/MCB.22.20.7105-19.2002.

8. Sato M, Watanabe Y, Akiyoshi Y, Yamamoto M. 14-33 protein interferes with the binding of RNA to the phosphorylated form of fission yeast meiotic regulator Mei2p. Curr Biol 2002; 12:141-5; PMID:11818066; http://dx.doi.org/10.1016/S0960-9822(01)00654-6.
9. Margolis SS, Perry JA, Forester CM, Nutt LK, Guo Y, Jardim MJ, et al. Role for the PP2A/B56delta phosphatase in regulating 14-3-3 release from Cdc25 to contro mitosis. Cell 2006; 127:759-73; PMID:17110335; http://dx.doi.org/10.1016/j.cell.2006.10.035.

10. Chaudhary J, Skinner MK. Characterization of a novel transcript of 14-3-3 theta in Sertoli cells. J Androl 2000; 21:730-8; PMID:10975420.

11. Berruti G. A novel rap1/B-Raf/14-3-3theta protein complex is formed in vivo during the morphogenetic differentiation of postmeiotic male germ cells. Exp Cell Res 2000; 257:172-9; PMID:10854065; http://dx.doi. org/10.1006/excr.2000.4877.

12. Graf M, Brobeil A, Sturm K, Steger K, Wimme M. 14-3-3beta in the healthy and diseased male reproductive system. Hum Reprod 2011; 26:59-66; PMID:21112954; http://dx.doi.org/10.1093/humrep/ deq319.

13. Wong EW, Sun S, Li MW, Lee WM, Cheng CY. 14-3-3 Protein regulates cell adhesion in the seminiferous epithelium of rat testes. Endocrinology 2009; 150:4713-23; PMID:19608648; http://dx.doi. org/10.1210/en.2009-0427.

14. Angrand PO, Segura I, Volkel P, Ghidelli S, Terry R, Brajenovic $M$, et al. Transgenic mouse proteomics identifies new 14-3-3-associated proteins involved in cytoskeletal rearrangements and cell signaling. $\mathrm{Mol}$ Cell Proteomics 2006; 5:2211-27; PMID:16959763; http://dx.doi.org/10.1074/mcp.M600147-MCP200.

15. Jin J, Smith FD, Stark C, Wells CD, Fawcett JP, Kulkarni S, et al. Proteomic, functional and domainbased analysis of in vivo 14-3-3 binding proteins involved in cytoskeletal regulation and cellular organization. Curr Biol 2004; 14:1436-50; PMID:15324660 http://dx.doi.org/10.1016/j.cub.2004.07.051.

16. Meek SE, Lane WS, Piwnica-Worms H. Comprehensive proteomic analysis of interphase and mitotic 14-3-3-binding proteins. J Biol Chem 2004; 279:32046-54; PMID:15161933; http://dx.doi. org/10.1074/jbc.M403044200

17. Pozuelo Rubio M, Geraghty KM, Wong BH, Wood NT, Campbell DG, Morrice N, et al. 14-3-3-affinity purification of over 200 human phosphoproteins reveals new links to regulation of cellular metabolism, proliferation and trafficking. Biochem J 2004, 379:395-408; PMID:14744259; http://dx.doi. org/10.1042/BJ20031797.
18. Ge F, Li WL, Bi LJ, Tao SC, Zhang ZP, Zhang XE Identification of novel 14-3-3zeta interacting proteins by quantitative immunoprecipitation combined with knockdown (QUICK). J Proteome Res 2010; 9:584858; PMID:20879785; http://dx.doi.org/10.1021/ pr100616g.

19. Pozuelo-Rubio M. Proteomic and biochemical analysis of 14-3-3-binding proteins during C2-ceramideinduced apoptosis. FEBS J 2010; 277:3321-42; PMID:20618440.

20. Puri P, Myers K, Kline D, Vijayaraghavan S. Proteomic analysis of bovine sperm YWHA binding partners identify proteins involved in signaling and metabolism. Biol Reprod 2008; 79:1183-91; PMID:18753613; http:// dx.doi.org/10.1095/biolreprod.108.068734.

21. Soler DC, Kadunganattil S, Ramdas S, Myers K, Roca J, Slaughter T, et al. Expression of transgenic PPP1CC2 in the testis of Ppplcc-null mice rescues spermatid viability and spermiation but does not restore normal sperm tail ultrastructure, sperm motility or fertility. Biol Reprod 2009; 81:343-52; PMID:19420386 http://dx.doi.org/10.1095/biolreprod.109.076398.

22. Varmuza S, Jurisicova A, Okano K, Hudson J, Boekelheide K, Shipp EB. Spermiogenesis is impaired in mice bearing a targeted mutation in the protein phosphatase 1cgamma gene. Dev Biol 1999; 205:98 110; PMID:9882500; http://dx.doi.org/10.1006/ dbio.1998.9100.

23. Danshina PV, Geyer CB, Dai Q, Goulding EH, Willis WD, Kitto GB, et al. Phosphoglycerate kinase 2 (PGK2) is essential for sperm function and male fertility in mice. Biol Reprod 2010; 82:136-45; PMID:19759366; http://dx.doi.org/10.1095/biolreprod.109.079699.

24. Henderson H, Macleod G, Hrabchak C, Varmuza $S$. New candidate targets of protein phosphatase1c-gamma-2 in mouse testis revealed by a differential phosphoproteome analysis. Int J Androl.

25. Van Der Hoeven PC, Van Der Wal JC, Ruurs P, Van Dijk MC, Van Blitterswijk J. 14-3-3 isotypes facilitate coupling of protein kinase C-zeta to Raf-1: negative regulation by 14-3-3 phosphorylation. Biochem J 2000; 345:297-306; PMID:10620507; http://dx.doi. org/10.1042/0264-6021:3450297. 
26. Moorhead GB, Trinkle-Mulcahy L, Nimick M, De Wever V, Campbell DG, Gourlay R, et al. Displacement affinity chromatography of protein phosphatase one (PP1) complexes. BMC Biochem 2008; 9:28; PMID:19000314; http://dx.doi.org/10.1186/14712091-9-28.

27. Rigaut G, Shevchenko A, Rutz B, Wilm M, Mann M, Seraphin B. A generic protein purification method for protein complex characterization and proteome exploration. Nat Biotechnol 1999; 17:1030-2 PMID:10504710; http://dx.doi.org/10.1038/13732.

28. Puig O, Caspary F, Rigaut G, Rutz B, Bouveret E, Bragado-Nilsson E, et al. The tandem affinity purification (TAP) method: a general procedure of protein complex purification. Methods 2001; 24:21829; PMID:11403571; http://dx.doi.org/10.1006/ meth.2001.1183.

29. Martin H, Patel Y, Jones D, Howell S, Robinson K, Aitken A. Antibodies against the major brain isoforms of 14-3-3 protein. An antibody specific for the $\mathrm{N}$-acetylated amino-terminus of a protein. FEBS Lett 1993; 331:296-303; PMID:8375512; http://dx.doi. org/10.1016/0014-5793(93)80356-Y.

30. Fuller B, Stevens SM Jr, Sehnke PC, Ferl RJ. Proteomic analysis of the 14-3-3 family in Arabidopsis. Proteomics 2006; 6:3050-9; PMID:16619310; http://dx.doi. org/10.1002/pmic.200500729.

31. Choudhary C, Kumar C, Gnad F, Nielsen ML, Rehman $\mathrm{M}$, Walther TC, et al. Lysine acetylation targets protein complexes and co-regulates major cellular functions. Science 2009; 325:834-40; PMID:19608861; http:// dx.doi.org/10.1126/science.1175371.

32. Paul AL, Liu L, Laughner B, McClung S, Chen S, Fer R. Comparative Interactomics: Analysis of Arabidopsis 14-3-3 complexes reveals highly conserved 14-3-3 interactions between humans and plants. J Proteome Res 2009.

33. Tanaka SS, Toyooka Y, Akasu R, Katoh-Fukui Y, Nakahara Y, Suzuki R, et al. The mouse homolog of Drosophila Vasa is required for the development of male germ cells. Genes Dev 2000; 14:841-53; PMID: 10766740

34. Tokuhiro K, Hirose M, Miyagawa Y, Tsujimura A, Irie S, Isotani A, et al. Meichroacidin containing the membrane occupation and recognition nexus motif is essential for spermatozoa morphogenesis. J Biol Chem 2008; 283:19039-48; PMID:18453535; http://dx.doi. org/10.1074/jbc.M708590200.

35. Yang J, Medvedev S, Yu J, Tang LC, Agno JE, Matzuk MM, et al. Absence of the DNA-/RNA-binding protein MSY2 results in male and female infertility. Proc Natl Acad Sci USA 2005; 102:5755-60; PMID:15824319; http://dx.doi.org/10.1073/pnas.0408718102.
36. Satoh J, Nanri Y, Yamamura T. Rapid identification of 14-3-3-binding proteins by protein microarray analysis. J Neurosci Methods 2006; 152:278-88; PMID:16260042; http://dx.doi.org/10.1016/j.jneumeth.2005.09.015.

37. Fujiwara Y, Komiya T, Kawabata H, Sato M, Fujimoto $\mathrm{H}$, Furusawa M, et al. Isolation of a DEAD-family protein gene that encodes a murine homolog of Drosophila vasa and its specific expression in germ cell lineage. Proc Natl Acad Sci USA 1994; 91:12258 62; PMID:7991615; http://dx.doi.org/10.1073/ pnas.91.25.12258

38. Boutros R, Fanayan S, Shehata M, Byrne JA. The tumor protein D52 family: many pieces, many puzzles. Biochem Biophys Res Commun 2004; 325:1115 21; PMID:15555543; http://dx.doi.org/10.1016/j. bbrc.2004.10.112

39. Boutros R, Bailey AM, Wilson SH, Byrne JA. Alternative splicing as a mechanism for regulating 14-3 3 binding: interactions between hD53 (TPD52L1) and 14-3-3 proteins. J Mol Biol 2003; 332:675-87; PMID:12963375; http://dx.doi.org/10.1016/S0022 2836(03)00944-6.

40. Lee MH, Schedl T. RNA-binding proteins. WormBook 2006; 1-13; PMID:18050487.

41. Díaz-Moreno I, Hollingworth D, Frenkiel TA, Kelly G, Martin S, Howell S, et al. Phosphorylation-mediated unfolding of a $\mathrm{KH}$ domain regulates KSRP localization via 14-3-3 binding. Nat Struct Mol Biol 2009; 16:23846; PMID:19198587; http://dx.doi.org/10.1038/ nsmb. 1558.

42. Kakiuchi K, Yamauchi Y, Taoka M, Iwago M, Fujita T, Ito $\mathrm{T}$, et al. Proteomic analysis of in vivo 14-3-3 interactions in the yeast Saccharomyces cerevisiae. Biochemistry 2007; 46:7781-92; PMID:17559233; http://dx.doi. org/10.1021/bi700501t

43. Platholi J, Heerdt PM, Lim Tung HY, Hemmings HC Jr. Activation of brain protein phosphatase-1(I) following cardiac arrest and resuscitation involving an interaction with 14-3-3gamma. J Neurochem 2008; 105:2029-38; PMID:18284617; http://dx.doi. org/10.1111/j.1471-4159.2008.05300.x.

44. Traweger A, Wiggin G, Taylor L, Tate SA, Metalnikov P, Pawson T. Protein phosphatase 1 regulates the phosphorylation state of the polarity scaffold Par-3. Proc Natl Acad Sci USA 2008; 105:10402-7; PMID:18641122; http://dx.doi.org/10.1073/pnas.0804102105.

45. Platt MD, Salicioni AM, Hunt DF, Visconti PE. Use of differential isotopic labeling and mass spectrometry to analyze capacitation-associated changes in the phosphorylation status of mouse sperm proteins. J Proteome Res 2009; 8:1431-40; PMID:19186949; http://dx.doi. org/10.1021/pr800796j.
46. Iida $\mathrm{H}$, Honda $\mathrm{Y}$, Matsuyama $\mathrm{T}$, Shibata $\mathrm{Y}$, Inai T. Spetex-1: a new component in the middle piece of flagellum in rodent spermatozoa. Mol Reprod Dev 2006; 73:342-9; PMID:16362971; http://dx.doi. org $/ 10.1002 / \mathrm{mrd} .20419$

47. Garnett MJ, Rana S, Paterson H, Barford D, Marais R. Wild-type and mutant B-RAF activate C-RAF through distinct mechanisms involving heterodimerization. $\mathrm{Mol}$ Cell 2005; 20:963-9; PMID:16364920; http://dx.doi. org/10.1016/j.molcel.2005.10.022.

48. Shi Y, Manley JL. A complex signaling pathway regulates SRp38 phosphorylation and pre-mRNA splicing in response to heat shock. Mol Cell 2007; 28:79-90; PMID:17936706; http://dx.doi.org/10.1016/j.mol cel.2007.08.028.

49. Bürckstümmer T, Bennett KL, Preradovic A, Schutze G, Hantschel O, Superti-Furga G, et al. An efficient tandem affinity purification procedure for interaction proteomics in mammalian cells. Nat Methods 2006; 3:1013-9; PMID:17060908; http://dx.doi. org/10.1038/nmeth968.

50. Li Y. The tandem affinity purification technology: an overview. Biotechnol Lett 2011; 33:1487-99; PMID:21424840; http://dx.doi.org/10.1007/s10529 011-0592-x.

51. Vijayaraghavan S, Stephens DT, Trautman K, Smith GD, Khatra B, da Cruz e Silva EF, et al. Sperm motility development in the epididymis is associated with decreased glycogen synthase kinase- 3 and protein phosphatase 1 activity. Biol Reprod 1996; 54:709-18; PMID:8835395; http://dx.doi.org/10.1095/biolreprod54.3.709.

52. Volkening K, Leystra-Lantz C, Yang W, Jaffee $\mathrm{H}$, Strong MJ. Tar DNA binding protein of $43 \mathrm{kDa}$ (TDP-43), 14-3-3 proteins and copper/zinc superoxide dismutase (SOD1) interact to modulate NFL mRNA stability. Implications for altered RNA processing in amyotrophic lateral sclerosis (ALS). Brain Res 2009; 1305:168-82; PMID:19815002; http://dx.doi. org/10.1016/j.brainres.2009.09.105

53. Pan S, Sehnke PC, Ferl RJ, Gurley WB. Specific interactions with TBP and TFIIB in vitro suggest that 14-3-3 proteins may participate in the regulation of transcription when part of a DNA binding complex. Plant Cell 1999; 11:1591-602; PMID:10449590.

54. Lopez P, Yaman R, Lopez-Fernandez LA, Vidal F, Puel $\mathrm{D}$, Clertant $\mathrm{P}$, et al. A novel germ line-specific gene of the phosducin-like protein (PhLP) family. A meiotic function conserved from yeast to mice. J Biol Chem 2003; 278:1751-7; PMID:12424248; http://dx.doi. org/10.1074/jbc.M207434200. 